\title{
SYNTHESIS AND CHARACTERISATION OF STRUVITE FAMILY CRYSTALS BY AN AQUEOUS PRECIPITATION METHOD
}

\author{
S.Sutiyono ${ }^{1}$, Luluk Edahwati ${ }^{1,2}$, Dyah Suci Perwitasari ${ }^{1,2}$, \\ Stefanus Muryanto ${ }^{2,3}$, J. Jamari ${ }^{2}$ and Anatasius P.Bayuseno ${ }^{2}$ \\ ${ }^{1}$ Departement of Chemical Engineering, University of Pembangunan Nasional "Veteran" Jatim. \\ ${ }^{2}$ Center for Waste Management, Mechanical Engineering Graduate Program, \\ Diponegoro University, Tembalang Campus, Semarang 50275, Indonesia. \\ ${ }^{2,3}$ Office of Research and Department of Chemical Engineering, UNTAG, Bendhan Dhuwur Campus, Semarang 50233, \\ Indonesia. \\ E-mail: apbayuseno@gmail.com
}

\begin{abstract}
Struvite $\left(\mathrm{NH}_{4} \mathrm{MgPO}_{4} \cdot 6 \mathrm{H}_{2} \mathrm{O}\right)$ is a mineral often found as a scale deposit in an industrial process and piping. The common occurrence of struvite formation is a wide variety of environments. $\mathrm{pH}$ solution and environmental temperature are important parameters that control precipitation and subsequent decomposition of struvite. The study aims to characterise the struvite precipitated out the solution through chemical and mineralogical analysis. In this work, struvite solution was prepared by mixing $\mathrm{NH}_{4} \mathrm{OH}, \mathrm{MgCl}_{2}$ and $\mathrm{H}_{3} \mathrm{PO}_{4}$ with the different purity grade (A and B) in the mol ratio of $1: 1: 1$ in the stirred glass vessel tank with volume of $500 \mathrm{ml}$, and then stirred at $200 \mathrm{rpm}$ for 70 minutes. Temperature of $30^{\circ} \mathrm{C}$ and an initial $\mathrm{pH}$ of 10 were selected. The precipitated deposit was dried at room temperature for 48 hours of being analyzed. Material characterization of the deposits was conducted using XRPD Rietveld method of qualitative and quantitative mineralogical phase analysis. XRF was employed for bulk chemical elemental analysis of the scale obtained. The sample A using analytical grade powder provided the major phases of struvite-(K) and struvite. In constrast, the major phase of newberyite and minor phases of lepidocrocite $(\mathrm{FeOOH})$ and niter $\left(\mathrm{KNO}_{3}\right)$ was observed by following changes in the lowest purity of powder (Sample B). Analysis of the experimental data suggests a solution mediated transformation process as a possible mechanism of struvite transformation.
\end{abstract}

Keywords: Bulk elemental analysis; Characterization; Struvite scalling, XRPD Rietveld method

\section{INTRODUCTION}

Struvite $\left(\mathrm{NH}_{4} \mathrm{MgPO}_{4} \cdot 6 \mathrm{H}_{2} \mathrm{O}\right)$ or magnesium ammonium phosphate (MAP) is a mineral often found as a precipitate in an industrial process and pipping system. Struvite precipitated in wastewater treatment plants make some problems causing deposits in pipe walls [Gaterell et al., 2000; Priestley et.al., 1997]. It is also known as a bio-mineral in urinary tracts and kidney. However, precipitation of struvite has been addressed as a recovery method of ammonia or phosphate from industrial and domestic wastewaters [Tünay et,al., 1997; Shin and Lee, 1997; Schulze-Rettmer, 1991; Snoeying and Jenkins, 1980; Loewenthal et.al., 1994]. It has attracted considerable attention because of its occurrence of different environments and its utility as a resource. Struvite has been reported to be a highly effective source of nitrogen, magnesium and phosphorus for plants and can be used as a slow release fertilizer at high application rates without damaging plant roots [Whitaker and Jeffery, 1970; Battistoni et.al., 1997; 2000].

Struvite precipitation may be controlled by an alkali pH levels and temperatures. Moreover, struvite decomposition occurs to a slow low heating, while this decomposition is accompanied by developing both ammonia and water at temperatures below $40^{\circ} \mathrm{C}$. However, more rapid heating enables the decomposition to occur at around $80^{\circ} \mathrm{C}$. Thus synthesis route of minerals from struvite-saturated solutions may be carried at high temperature due to the increasing solubility of struvite.

Further, in the air, struvite may transform to form dittmarite $\left(\mathrm{MgNH}_{4} \mathrm{PO}_{4} \mathrm{H}_{2} \mathrm{O}\right)$ at $103{ }^{\circ} \mathrm{C}$ [Abdelrazig and Sharp, 1988], but in water, it decomposes slightly at lower temperature of $60{ }^{\circ} \mathrm{C}$ [Sarkar, 1991]. Additionally, the remaining water of crystallisation and $\mathrm{NH}_{4}$ are liberated at $235^{\circ} \mathrm{C}$ and followed by formation of the pyrophosphate at $575 \mathrm{C}$ [Abdelrazig and Sharp, 1988]. Here, magnesium pyrophosphate is considered as the most stable phase at high temperature. However, the different minerals may be produced in-between temperature. The stable temperature range of struvite decomposition may be related to the occurring process in the presence of nitrogen, air, or water [Frost et al., 2004]. In turn, the presence of water enables the stable temperature range of the generated minerals to lower values. Thus, this conditional process can provide important 
information about the possible resulting minerals from struvite-saturated solutions to elevated Struvite precipitation occurs to the presence of $\mathrm{Mg}^{+2}(\mathrm{M}), \mathrm{NH}_{4}^{+}(\mathrm{N})$ and $\mathrm{PO}_{4}^{-3}(\mathrm{P})$ and the thermodynamic solubility product, $K_{s}$, is surpassed according to following reaction:

$$
\begin{array}{r}
\mathrm{Mg}^{2+}+\mathrm{NH}_{4}^{+}+\mathrm{PO}_{4}^{3-}+6 \mathrm{H}_{2} \mathrm{O} \rightarrow \mathrm{MgNH}_{4} \mathrm{PO}_{4} \cdot 6 \mathrm{H}_{2} \mathrm{O} \\
K_{S}=\left\lfloor\mathrm{Mg}^{2+}\left\lfloor\mathrm{NH}_{4}^{+}\right\rfloor \mathrm{PO}_{4}^{3-}\right\rfloor
\end{array}
$$

However, the precipitation of struvite has been reported to reduce with the $\mathrm{pH}$, in which $\mathrm{HPO}_{4}{ }^{-2}$ is predominantly precipitated in the reaction instead of $\mathrm{PO}_{4}{ }^{-3}$ according to following reaction:

$$
\mathrm{Mg}^{2+}+\mathrm{NH}_{4}^{+}+\mathrm{HPO}_{4}^{2-}+6 \mathrm{H}_{2} \mathrm{O} \rightarrow \mathrm{MgNH}_{4} \mathrm{PO}_{4} \cdot 6 \mathrm{H}_{2} \mathrm{O}+\mathrm{H}^{+}
$$

Struvite crystals have been reported to be formed in the $\mathrm{pH}$ range of $7-11$. In this range $\mathrm{pH}, \mathrm{a}$ few crystals may be formed including trimagnesium phosphate $\quad\left[\mathrm{Mg}_{3}\left(\mathrm{PO}_{4}\right)_{2} \bullet 6 \mathrm{H}_{2} \mathrm{O}\right]$ newberyite $\left[\mathrm{MgHPO}_{4} \cdot 3 \mathrm{H}_{2} \mathrm{O}\right]$, and bobierrite $\left[\mathrm{Mg}_{3}\left(\mathrm{PO}_{4}\right)_{2} \bullet 8 \mathrm{H}_{2} \mathrm{O}\right]$ [Musvoto et al., 2000]. Here, the solution $\mathrm{pH}$ and concentration of magnesium and phosphate controls the formation of these crystals.

The present study was undertaken to examine temperature and $\mathrm{pH}$ on struvite crystallization. The emphasis of this study was to synthesize struvite crystals and discuss the impact on the quality of the recovered product. The degree of crystallization for struvite products was analyzed by the Rietveld refinement method of X-ray powder diffraction (XRPD). Total elemental composition of solid crystals was conducted by wavelength dispersive X-ray fluorescence (XRF).

\section{METHODOLOGY}

\section{Sample preparation}

Struvite precipitation experiments were carried out in a batch reactor with a volume of $500 \mathrm{ml}$ mixed with magnetic stirrer. The $\mathrm{pH}$ measurements are made with $\mathrm{pH}$ meter E588 Metrohm Herisau and $\mathrm{pH}$ is adjusted by $\mathrm{KOH}$ solutions. The chemicals used for synthesis were technical and analytical grade and hereby designated as sample $\mathrm{A}$ and $\mathrm{B}$. In this work, struvite solution was prepared by mixing $\mathrm{NH}_{4} \mathrm{OH}, \mathrm{MgCl}_{2}$ and $\mathrm{H}_{3} \mathrm{PO}_{4}$ in the mol ratio of $1: 1: 1$ temperature. But it cannot be used to predict the mineral formation of the solution.

and then stirred at $200 \mathrm{rpm}$ for 70 minutes. Temperature of $30{ }^{\circ} \mathrm{C}$ and an initial $\mathrm{pH}$ of 10 were adjusted. The precipitated deposit was dried at room temperature for 48 hours of being analysed.

\section{Bulk chemical analysis}

X-ray fluorescence (XRF) was employed for measurement of total elemental chemistry (mass of element/dry mass of solid crystal) with lower detection limits (LDL)- down to a few ppm (order of less than $10 \mathrm{ppm})$ for all size fractions $(<100 \mu \mathrm{m})$ of the solid crytals. Further, batches of 8 grams of the sample were mixed with $2 \mathrm{~g}$ of acetone as a binder. The acetone was employed to increase sample densification. The mixture was finely homogenised in an agate bowl. The powder pellets were subsequently pressed on $20 \mathrm{Kg} / \mathrm{cm}^{2}$ for 2 minutes and finally analyzed by XRF for all elements present in the solid, except for those lighter than fluorine (atomic mass $=19$ ).

\section{X-ray powder diffraction (XRPD) and Rieveld analysis}

XRPD measurements were conducted on A Philips PW 1710 Diffractometer equipped with a $\mathrm{Cu}$ tube and measurement parameters: $40 \mathrm{kV}, 40 \mathrm{~mA}$, $0.02^{\mathrm{O}}$ step, $2 \mathrm{~s}$ per step, $5-90^{\circ} 2 \theta$. Phase identification was made with (Powder Diffraction File)-PDF-2 Phillips software. Rietveld refinement of the XRPD data was carried out with Program Fullprof-2k, version 3.30 [Rodriguez-Carvajal, 2005], with the crystal structure database from the published data in Mineralogical Society of America (see Table 1). Results presented here were obtained with refining fundamental parameters such as: the $2 \theta$ scale zero position, the polynomial fitting for the background with six coefficients, the phase scale factors, the cell parameters, the peak asymmetry and the peak shape functions, the atomic coordinates, anisotropic temperature factors, and the preferred orientation for struvite family crystal with Marchmodel. Site occupation factors were not refined during Rietveld refinement, because of all struvite peaks are overlapped by peaks of other minerals. The error of the Rietveld quantifications can be estimated to about 2 wt. $\%$ ( $1 \rho)$ per phase. 
Table-1. Crystal structure models used in Rietveld refinements

\begin{tabular}{lll}
\hline Structure models & PDF number & \multicolumn{1}{c}{ Authors } \\
\hline Struvite $\left[\mathrm{MgNH}_{4} \mathrm{PO}_{4} \cdot 6 \mathrm{H}_{2} \mathrm{O}\right]$ & PDF\#71-2089 & Whitaker and Jeffery (1970) \\
Stuvite- $(\mathrm{K})\left[\mathrm{KMgPO} \cdot 6 \mathrm{H}_{2} \mathrm{O}\right]$ & PDF\#35-0812 & Graeser et al. (2008) \\
Newberyite $\left[\mathrm{MgHPO}_{4} \cdot 3 \mathrm{H}_{2} \mathrm{O}\right]$ & PDF\# 76-3368 & Abbona et al. (1979) \\
Lepidocrocite $[\mathrm{FeOOH}]$ & PDF\#89-6096 & Pernet, Joubert, Berthet-Colominas. (1975) 17, 1505 \\
Niter $\left[\mathrm{KNO}_{3}\right]$ & PDF\#81-0070 & Lu, H.M., Hardy.(1991). 44, 7215 \\
\hline
\end{tabular}

The final Rietveld scale factors were converted to PCs-by-weight using the "ZMV" expressions below:

wt.\% (analyte phase $)=\frac{[\mathrm{s}(\mathrm{ZMV}] \text { analyte phase }}{\Sigma[s(Z M V)] \text { all phase }}$

where s, Z, M and V signify the phase scale factors; number of formula units/cell; formula weights and unit cell volumes, respectively.

\section{RESULTS}

Bulk chemical compositions

Chemical compositions of the crystal solid were analysed for major and trace elements. The chemical compositions are presented in the form of element weight percents, independent of the actual form of chemical binding in the residues. The light elements oxygen and carbon could not be analysed. However, the cations may be mainly bound in oxide compounds.

Table 2. Chemical elements of precipitating solids

\begin{tabular}{lcccccccccc}
\hline Elements & $\mathrm{P}$ & $\mathrm{Mg}$ & $\mathrm{K}$ & $\mathrm{Ca}$ & $\mathrm{Ni}$ & $\mathrm{Fe}$ & $\mathrm{Cu}$ & $\mathrm{Ti}$ & $\mathrm{Cr}$ & $\mathrm{Zn}$ \\
\hline Wt.\% & 61.9 & 12.0 & 9.8 & 8.5 & 4.3 & 1.2 & 0.7 & 0.6 & 0.3 & 0.2 \\
Esd & 1.4 & 2.0 & 0.1 & 0.4 & 0.3 & 0.1 & 0.1 & 0.1 & 0.1 & 0.0 \\
\hline
\end{tabular}

\section{Powder XRD analysis}

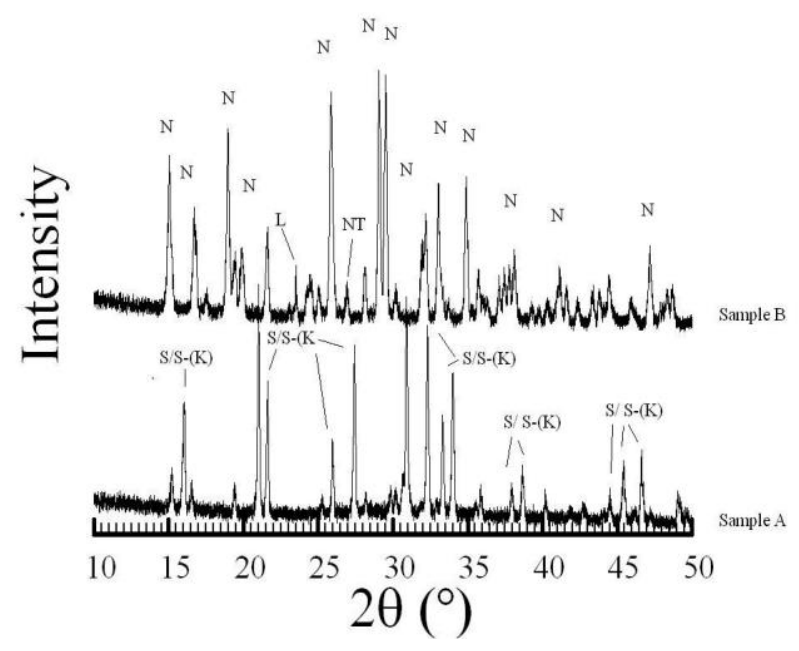

Figure-1. XRPD pattern of the samples $\mathrm{A}$ and $\mathrm{B}$ obtained at temperature of $30^{\circ} \mathrm{C}$ and $\mathrm{pH} 10$. The principal diffraction peaks of the predominant minerals are shown for reference purposes. The peaks are labelled $\mathrm{L}$ (lepidocrocite); N (newberyite); NT (niter); S (struvite), and S-(K) (struvite K) . 
Table 3 Mineralogical phase composition of the synthetic materials using samples of A and B

\begin{tabular}{lrr|lrr}
\hline \multicolumn{2}{c|}{ Sample A } & \multicolumn{3}{c}{ Sample B } \\
\cline { 2 - 3 } & \multicolumn{2}{c}{ wt.\% } & eds & & \multicolumn{2}{c}{ wt.\% } & eds \\
\cline { 2 - 3 } Struvite-(K) & 87.64 & 1.08 & Newberyite & 96.91 & 0.61 \\
Struvite & 12.36 & 0.88 & Lepidocrocite & 1.40 & 0.01 \\
& & & Niter & 1.69 & 0.04 \\
\hline Total & 100.00 & Total & 100.00 & \\
\hline
\end{tabular}

\section{DISCUSSIONS}

Table 2 presents the chemical compositions of the crystal solid. The sum of the major components and trace element concentrations for these materials are notably less than $100 \%$, because the remainder of the materials may comprise largely water and carbon dioxide (which were not analysed for).

The mineralogy phases of crystal solid controlling the magnesium, ammonium, phosphate levels in the solution were initially identified by XRPD search-match method. In this method, all XRPD patterns of sample A agree well with the PDF\#71-2089 value for struvite, and the DF\#35-0812 value for struvite-(K), while PDF\#70-2345 value for newberyite $\left[\mathrm{MgHPO}_{4} \cdot 3 \mathrm{H}_{2} \mathrm{O}\right]$, PDF\# 76-2301 value for lepidocrocite [FeOOH] and PDF\#81-0070 value for niter $\left[\mathrm{KNO}_{3}\right]$ were found in the sample $\mathrm{B}$. The 'candidate and/or probable' minerals found in the search-match program were subsequently proved by the full profile Rietveld refinement, as peaks of phases which have been missed in the search match or mistakenly assigned phases clearly stand out in the difference plot of the calculated and the measured diffraction profile (Prince, 1993; Rietveld, 1969; Winburn et al., 2000) (fig.1).

The quantitative results are given in weight percent normalised to $100 \%$. The major mineralogical phases in the sample A are struvite-(K) in addition to struvite. The significant amount of newberyite is obtained in the sample B with some minor of lepidocrite and nitrite produced. This indicates that the use of different chemical grade in solution provided the different minerals, although the molar ratio is same. The highest purity of chemical powder has influenced the formation of struvite family crystals, but the lowest purity may be favoring in formation of newberyite crystals.

Both the struvite and struvite-(K) has been known to be iso-structural minerals [Graeser et.al, 2008]. The struvite-(K) precipitation may occur in the solution according to following reaction:

$$
\mathrm{Mg}^{2+}+\mathrm{K}^{+}+\mathrm{PO}_{4}^{3-}+6 \mathrm{H}_{2} \mathrm{O} \rightarrow \mathrm{KMgPO}_{4} \bullet 6\left(\mathrm{H}_{2} \mathrm{O}\right)_{(\text {solid })}(5)
$$

The presence of $\mathrm{KOH}$ in the solution may react to ions of $\mathrm{Mg}^{2+}$ and $\mathrm{PO}_{4}{ }^{3-}$ to form struvite-(K). Here $\mathrm{Mg}^{2+}$ ion was partly consumed for this mineral, while the rest of $\mathrm{Mg}$ ion may be used for struvite formation. Moreover, solution $\mathrm{pH}$ controls the distribution ammonia nitrogen between $\mathrm{NH}_{4}{ }^{+}$and $\mathrm{NH}_{3}$ according to following equilibrium reaction:

$$
\mathrm{NH}_{4}^{+}+\mathrm{H}_{2} \mathrm{O} \Leftrightarrow \mathrm{NH}_{3}+\mathrm{H}_{3} \mathrm{O}^{+}
$$

where the equilibrium constant $\left(\mathrm{K}_{\mathrm{a}}\right)$, is defined as [Stumm and Morgan, 1996].

$$
K_{a}=\frac{\left[\mathrm{NH}_{3}\right]\left[\mathrm{H}_{3} \mathrm{O}^{+}\right]}{\left[\mathrm{NH}_{4}^{+}\right]}=5.7 * 10^{-10}
$$

The high $\mathrm{pH}$ values have been reported to favor $\mathrm{NH}_{3}$ formation which is in equilibrium with air according to Henry Law and promotes air stripping of ammonia [Stumm and Morgan, 1996]. At pH 10 examined during the study, much ammonia could be lost at $30{ }^{\circ} \mathrm{C}$, resulting to the minor struvite formation. In contrast, newberyite was found in quite abundance in the sample B. Newberyite is known as a rare mineral and can be formed in the absence of ammonium. The absence of ammonium may be lost at the temperature studied.This mineral was subsequently precipitated out the solution according to the following reaction [Abbona et al., 1979]:

$\mathrm{Mg}^{+2}+\mathrm{HPO}_{2}{ }^{-4}+3 \mathrm{H}_{2} \mathrm{O} \rightarrow \mathrm{MgHPO}_{4} \cdot 3 \mathrm{H}_{2} \mathrm{O}_{\text {(solid) }}$

The formation of this mineral is commonly accompanied by other phosphates (e.g. struvite and hannayite) [Abbona et al 1988]. Here $\mathrm{pH}$ and molar ratio of MAP concentration are particularly an important parameter in the crystal formation and aggregation. The significant amount of newberyite was produced in the study, because this mineral can be developed significantly with MAP of 1:1:1 molar ratio [Abbona et al., 1979]. 


\section{CONCLUSIONS}

The study proved that the use of different purity of material in the synthesis of struvite provided the different minerals. Use of the technical grade material enables major struvite to form in the condition $\mathrm{pH}$ selected. In contrast, newberyite is the major mineral in the synthesis of material using the analytical grade chemical. As shown in Table 2 where certain hazardous substances such as $\mathrm{Cu}, \mathrm{Cr}$ and $\mathrm{Zn}$ can also be shipped in the process of formation of struvite. It is also reinforced by the results shown in Table 3 where the purity of the chemical will affect the results stuvite formed though the same molar ratios are used.The $\mathrm{pH}$ for ammonia recovery as struvite precipitation in the technical grade sample is 10 . However, the same $\mathrm{pH}$ used in the analytical grade sample has experienced the loss of ammonia to air due to stripping since high $\mathrm{pH}$ favors NH3. Newberyite precipitation has also been observed as low as $\mathrm{pH} 10$.

\section{Acknowledgements}

The work was supported by the University of Pembangunan National, Surabaya Indonesia under the $\mathrm{PhD}$ research grant program.

\section{REFERENCES}

Abbona F., Boistelle R., Haser R. (1979). Hydrogen bonding in $\mathrm{MgHPO}_{4} \cdot 3 \mathrm{H}_{2} \mathrm{O}$ (newberyite). Acta Crystallographica, B35, 2514-2518.

Abdelrazig B.E.I., Sharp J.H. (1988). Phase changes on heating ammonium magnesium phosphate hydrates. Thermochimica Acta 129,197-215.

Abbona F., Lundager Madsen H. E., Boistelle R. (1988). The final phases of calcium and magnesium phosphates precipitated from solutions of high to medium concentration J. Cryst. Growth. 89, 592-602.

Battistoni P., Fava G., Pavan P., Musacco A., Cecchi F. (1997). Phosphate Removal in Anaerobic Liquors by Struvite Crystallization Without Addition of Chemicals: Preliminary Results, Wat. Res., 31, 29252929.

Battistoni P., Pavan P., Prisciandaro M., Cecchi F. (2000). Struvite Crystallization: A feasible and reliable way to fix phosphorus in anaerobic supernatants, Wat. Res., 34, 3033-3041.
Frost R.L., Weier M.L., Erickson K.L. (2004). Thermal decomposition of struvite, J. Therm. Anal. Calorim. 76,1025-1033.

Gaterell M.R., Gay R., Wilson R., Gochin R.J., Lester J.N. (2000). An economic and environmental evaluation of the opportunities for substituting phosphorus recovered from wastewater treatment works in existing UK fertiliser markets, Env. Technol., 21, 1067-1084.

Graeser S., Wostl W., Bojar H.P., Berlepsch P., Armbruster T., Raber T., Ettinger K., Walter F. (2008). Struvite-(K), $\mathrm{KMgPO} 4 \cdot 6 \mathrm{H}_{2} \mathrm{O}$, the potassium equivalent of struvite a new mineral. European Journal of Mineralogy 20, 629-633.

Lu H. M. and Hardy J. R. (1991). First-principles study of phase transitions in $\mathrm{KNO}_{3}$. Physical Review. B 44, 7215.

Loewenthal R.E., Kornmuller U.R.C., Van Heerden E.P. (1994). Struvite Precipitation in Anaerobic Treatment Systems, In $17^{\text {th }}$ International Symposium on Anaerobic Digestion, Capetown, South Africa,498-507.

Musvoto E. V., Wentzel M. C., Ekama G.A. (2000). Integrated Chemical-Physical Process Modeling-Ii. Simulation Aeration Treatment For Anaerobic Digester Supernatant. Water Research, 34, 1868 1880.

Pernet M., Joubert J.C., Berthet-Colominas C. (1975). Etude par diffraction neutronique de la forme haute pression de FeOOH, Solid State Communications, Volume 17, Issue 12, 15, Pages 1505-1510.

Priestley A.J., Cooney E., Booker N.A., Fraser I.H. (1997). Nutrients in wastewaters-ecological problem or commercial opportunity. Proceedings of the $17^{\text {th }}$ Federal Convention of the Australian Water and Wastewater Association, Melbourne, 1, 340-346.

Rodriguez-Carvajal J., Program Fullprof.2k, version 3.30, Laboratoire Leon Brillouin, France, June 2005.

Snoeying V.L., Jenkins D. (1980). Water Chemistry, John Wiley and Sons Inc., New York.

Sarkar A.K. (1991). Hydration/dehydration characteristics of struvite and dittmarite pertaining to magnesium ammonium phosphate cement systems. J. Mater. Sci., 26, 2514-2518. 
Schulze-Rettmer R. (1991). The Simultaneous Chemical Precipitation of Ammonium and Phosphate in the Form of Magnesium Ammonium Phosphate, Water Sci. Technol., 23, 659-667

Stumm W., Morgan J.J. (1996). Aquatic Chemistry, Wiley-Interscience, New York .

Shin H.S., Lee S.M. (1997). Removal of Nutrients in Wastewater by Using Magnesium Salts, Env. Technol., 19, 283-290.
Tünay O., Kabdasli I., Orhon D., Kolçak S. (1997). Ammonia removal by magnesium ammonium phosphate precipitation in industrial wastewaters, Water Sci. Technol., 36, 225-228.

Whitaker A., Jeffery J.W. (1970) . The crystal structure of struvite, $\mathrm{MgNH}_{4} \mathrm{PO}_{4} \cdot 6 \mathrm{H}_{2} \mathrm{O}$. Acta Crystallographica B26,1429-1440. 